\title{
PENGEMBANGAN BUKU AJAR TEMATIK KELAS IV BERBASIS INTEGRASI ISLAM PADA SUBTEMA PEMANFAATAN ENERGI DI SEKOLAH DASAR
}

\author{
Muhammad Walid, Nur Hidayah Hanifah \\ Universitas Islam Negeri (UIN) Maulana Malik Ibrahim Malang \\ Email: walidpgmi@gmail.com
}

Naskah diterima : 05 September 2017, direvisi : 02 Oktober 2017, disetujui : 12 Oktober 2017

\begin{abstract}
The development of thematic teaching book with subtheme energy utilization is one of the facilities to help students understand during learning process. By using teaching book, the purpose is to motivate and initiate the creativity of the students, and an effort to form their habit to work hard in order to gain knowledge, without teacher's assistance. The teaching book to support the learning process with subtheme energy utilization is Islam-integration-based teaching book, in the form of teaching book for IV grader of elementary school.

Product specification resulting from research and development is to produce a textbook integration of Islam based thematic sub-themes of energy utilization. Textbooks thematic sub-themes of energy in it presses right on the breadth of material content and concept of learning so that students can better understand the lesson. In addition to emphasis the concept, teaching materials fitted with the integration of Islam and the end of each lesson there is a verse of the Qur'an that can foster a love of students of the Qur'an.

The result of the study has validity criteria score from the material expert is $94 \%$, media expert is $90 \%$, subject expert is $94 \&$, and the result of the field testing is $92 \%$. The students' average score for the pre-test is 71 and for the post-test is 91 . In manual t-test with significance level 0,05 , the result shows that $\mathrm{t}$ hitung $\geq \mathrm{t}$ tabel is $3,891015 \geq 1,701$, means that Ho is rejected and $\mathrm{Ha}$ accepted. Thus, it shows that there is significant difference toward the teaching book which is developed. It shows that the developed product has high validation level of qualification, means that the book is appropriate to be used in learning processes.
\end{abstract}

Keywords: development, teaching book, Islam Integration, energy utilization

Pengutipan: Walid, Muhammad, \& Nur Hidayah Hanifah. (2017). Pengembangan Buku Ajar Tematik Kelas IV Berbasis Integrasi Islam pada Subtema Pemanfaatan Energi di Sekolah Dasar. JMIE: Journal of Madrasah Ibtidaiyah Education, 1(2), 2017, 259-274. jmie. v1i2.45. 


\section{LATAR BELAKANG MASALAH}

Belajar adalah suatu proses yang kompleks yang terjadi pada diri setiap orang sepanjang hidupnya. Proses belajar itu terjadi karena adanya interaksi antara seseorang dengan lingkungannya. Oleh karena itu belajar dapat terjadi kapan saja dan dimana saja. Salah satu pertanda bahwa seseorang itu telah belajar adalah adanya perubahan tingkah laku pada diri orang itu yang mungkin disebabkan oleh terjadinya perubahan pada tingkat pengetahuan, keterampilan, atau sikapnya. (Azhar Arsyad, 1997)

Belajar dan pembelajaran adalah satu kesatuan yang saling berkaitan satu sama lain. Belajar adalah proses dimana suatu aktivitas berasal atau berubah melalui reaksi pada situasi yang ditemui, selama ciri perubahan aktivitasnya tidak dapat dijelaskan sebagai kecenderungan respon dasar, kematangan, atau proses tubuh organisma yang bersifat sementara. Sedangkan pembelajaran adalah usaha sadar yang dilakukan oleh guru untuk membelajarkan peserta didik agar mau dan mampu belajar.

Komponen pembelajaran antara lain adalah kesiapan siswa dan guru, ketersediaan bahan ajar, kurikulum, fasilitas dan pengelolaan. Bahan ajar merupakan salah satu komponen yang memiliki pengaruh yang signifikan terhadap proses belajar mengajar. Bahan ajar merupakan sumber belajar yang cukup penting dalam kegiatan belajar siswa. Hal ini disebabkan interaksi siswa dengan bahan ajar dan media inilah yang sebenarnya wujud nyata dari tindak belajar (Dedeng, 1989).

Bahan ajar sebagai salah satu media pembelajaran, mempunyai peranan penting dalam proses pembelajaran yaitu sebagai acuan bagi siswa dan guru untuk meningkatkan efektifitas pembelajaran. Bagi siswa, bahan ajar menjadi bahan acuan yang diserap isinya dalam proses belajar sehingga dapat menjadi pengetahuan. Sedangkan bagi guru, bahan ajar menjadi salah satu acuan penyampaian ilmu kepada siswa. (Belawati, 2003).

Ada banyak bahan ajar yang tersedia di pasaran, ada juga buku paket bahan ajar yang sudah disusun secara nasional oleh Depdiknas. Namun demikian, merupakan sebuah tanggung jawab profesional bagi guru, maupun pihak yang berkepentingan untuk tetap mengembangkan sendiri bahan ajar yang dibutuhkan untuk pembelajarannya. Hal ini dikarenakan dunia pendidikan adalah dunia yang dinamis sedinamis manusia sebagai subyek belajarnya dengan berbagai konteks sosial, ekonomi, budaya, politik yang selalu melatari sepanjang waktu. Merupakan sebuah keniscayaan bahwa tuntutan hidup beserta tantangannya selalu menghantui perjalanan hidup manusia. Demikian halnya dengan keberadaan kurikulum yang sering berganti dalam waktu yang relatif cepat sebagai konsekuensi kebutuhan dunia pendidikan dengan manusia sebagai subyeknya, belum tentu dapat diikuti dengan kecepatan pengadaan bahan ajar untuk siswa, sehingga pengembangan bahan ajar mutlak diperlukan (Asnawir \& Basyiruddin Usman, 2002).

Di sekolah Dasar maupun Madrasah Ibtidaiyah saat ini banyak menggunakan berbagai macam bahan ajar dalam pembelajaran. Akan tetapi tidak sedikit bahan ajar yang digunakan tidak sesuai dengan konsep yang seharusnya disampaikan. Selain itu pembahasan hanya poin-poin tertentu yang disampaikan. Apalagi dengan adanya kurikulum baru yaitu kurikulum 2013 yang pendalaman konsepnya masih sangat sedikit. Disamping tidak sesuainya konsep dan materi yang disampaikan, suatu bahan ajar harus mempunyai sesuatu yang menarik dari isi dan tampilan bahan ajar tersebut. Menariknya suatu bahan ajar juga harus diimbangi dengan tersampaikannya materi kepada peserta didik. Diharapkan 
tersampaikannya materi kepada siswa tidak hanya diketahui akan tetapi siswa juga paham terhadap konsep materi. Pemahaman konsep peserta didik merupakan tujuan utama dalam proses pembelajaran.

Untuk memahamkan peserta didik pada suatu konsep, di dalam bahan ajar harus memiliki suatu metode yang menjadi ciri khas dari bahan ajar. Metode yang menjadi ciri khas dari bahan ajar tersebut juga harus menyesuaikan permasalahan yang akan diselesaikan. Dilihat dari masalah yang ditemukan, maka sangat perlu dilakukan suatu pengembangan bahan ajar yang dirancang secara sistematis untuk memperbaiki bahan ajar yang sudah ada. Bahan ajar yang dikembangkan akan membuat siswa lebih baik lagi dalam proses belajar dan dapat meningkatkan hasil belajar siswa.

Bahan ajar memiliki pengaruh dan peran sangat tinggi dalam proses pembelajaran. Hal ini disebabkan adanya hubungan guru, sumber belajar dan sisiwa. Oleh sebab itu penulis ingin membuat buku ajar yang berbasis integrasi Islam, dengan tujuan siswa SD atau MI akan memperoleh pengetahuan umum dan pengetahuan agama secara maksimal, dan lebih mencintai Al-Qur'an karena membiasakan siswa untuk membaca Al-Qur'an setiap harinya. Bahan ajar yang menggunakan desain majalah serta luasnya materi yang ada di dalam buku ajar ini akan lebih menarik siswa untuk lebih semangat dalam belajar dan meningkatkan hasil belajar bagi siswa. Al-Qur'an adalah firman Allah yang berfungsi sebagai mukjizat yang diturunkan kepada Nabi Muhammad yang tertulis dalam mushafmushaf, yang diriwayatkan secara mutawatir, dan membacanya merupakan ibadah (Mustamir , 2007: 5). Hal ini merupakan keinginan untuk melaksanakn tujuan pembelajaran yaitu untuk memperoleh pengetahuan dengan suatu cara yang dapat melatih kemampuan intelektual para siswa dan merangsang keingintahuan serta memotivasi kemampuan mereka serta penanaman kebiasaan dalam membaca Al-Qur'an.

Berdasarkan observasi di Sekolah Dasar Negeri Kebonsari 1 Kota Malang, sekolah sudah menggunakan kurikulum 2013 dan bahan ajar yang di pakai adalah bahan ajar yang seperti bahan ajar biasanya dari pemerintah. Namun, siswa kelas IV Sekolah Dasar Negeri Kebonsari 1 Kota Malang kurang memahami tentang materi tematik yang ada di buku yang diberikan pemerintah karena buku ajar ini masih banyak kekurangannya. Buku tematik ini langsung memberikan perintah- perintah pengerjaan tanpa lebih jauh dalam penjelasan konsepnya. Di samping itu, buku tersebut tidak terdapat integrasi Islam. Padahal dalam pelaksanaannya dalam KI 1 dijelaskan mengenai pemahaman akhlak siswa, serta KI 2 yang menekankan sikap siswa yang berperilaku jujur, tanggung jawab, disiplin, dan lain sebagainya.

Sejauh ini siswa Sekolah Dasar Negeri Kebonsari 1 Kota masih banyak mengalami kesulitan dalam pembelajaran tematik di kelas IV, dengan singkatnya penjelasan materi pelajaran tersebut dan kurang mengaitkannya dalam kehidupan sehari- hari secara lebih luas, apalagi kurikulum 2013 yang baru terlaksana. Oleh karena itu siswa harus diberi pemahaman mendalam tentang pentingnya belajar yang berkarakter dengan pendalaman Al Qur'an dan nilai keIslaman dengan pengembangan buku ajar yang berbasis integrasi Islam menggunakan cara, metode dan teknik yang baik untuk belajar. Supaya hasil dari pembelajaran tematik di kelas IV tema 2 subtema 2 ini bejalan dengan baik.

Berdasarkan paparan latar belakang di atas, peneliti tertarik untuk melakukan penelitian dan pengembangan bahan ajar untuk memperoleh data tentang; (1) Bagaimana spesifikasi produk buku ajar tematik kelas IV berbasis integrasi Islam pada subtema peman- 
faatan energi yang dikembangkan di Sekolah Dasar Negeri Kebonsari 1 Kota Malang?, (2) Bagaimana tingkat validitas dan kemenarikan buku ajar tematik kelas IV berbasis integrasi Islam pada subtema pemanfaatan energi yang dikembangkan di Sekolah Dasar Negeri Kebonsari 1 Kota Malang? Dan (3) Bagaimana efektifitas buku ajar tematik kelas IV berbasis integrasi Islam pada subtema pemanfaatan energi dalam meningkatkan hasil belajar siswa yang dikembangkan di Sekolah Dasar Negeri Kebonsari 1 Kota Malang?

Penelitian ini bertujuan untuk; (1) Mengembangkan dan memproduk buku ajar tematik kelas IV berbasis integrasi Islam pada subtema pemanfaatan energi yang dikembangkan di Sekolah Dasar Negeri Kebonsari 1 Kota Malang; (2) Menjelaskan tingkat validitas dan kemenarikan buku ajar tematik kelas IV berbasis integrasi Islam pada subtema pemanfaatan energy di Sekolah Dasar Negeri Kebonsari 1 Kota Malang; dan (3) Menjelaskan pengaruh buku ajar tematik kelas IV berbasis integrasi Islam pada subtema pemanfaatan energi terhadap hasil belajar siswa yang dikembangkan di Sekolah Dasar Negeri Kebonsari 1 Kota Malang.

Kegunaan dari pengembangan buku ajar ini adalah; (1) bagi siswa; meningkatkan pemahaman konsep tematik pada kelas 4 tema 2 subtema 2 dan lebih bisa mendalami AlQur'an sehingga mendapatkan makna dari sebuah pembelajaran dengan menggunakan bahan ajar berbasis integrasi Islam; memberikan kemudahan bagi siswa untuk belajar, memotivasi siswa dan lebih mendalami Al-Qur'an dalam proses pembelajaran; siswa lebih termotivasi dan semangat dalam pembelajaran, sehingga dalam proses pembelajaran tidak monoton dengan bahan ajar yang kurang bervariatif. (2) Bagi guru; pengembangan bahan ajar ini bisa dijadikan buku pedoman tambahan bagi seorang guru dalam pembelajaran tematik di kelas IV tema 2 subtema 2. Sehingga bahan ajar yang digunakan akan lebih berinovasi untuk membantu memahamkan siswa dan menambah kecintaan siswa terhadap Al-Qur'an; (3) Bagi peneliti lain; penelitian ini dapat dijadikan bahan referensi dan pertimbangan bagi peneliti lain untuk membantu dalam penyelesaian penelitiannya; (4) Bagi pengembangan teori; dijadikan masukan dalam pengembangan bahan ajar supaya lebih kreatif, inovatif, religi dan menyenangkan dalam peoses pembelajaran tematik; bahan ajar ini dapat djadikan rujukan dalam tambahnya pengetahuan dalam meningkatkan kualitas pendidikan dan kesiapan para pendidik jika nantinya menjadi tenaga pendidik dalam mengembangkan bahan ajar yang lebih menarik dan berkualitas.

\section{METODE PENELITIAN}

\section{Jenis Penelitian}

Dalam penelitian ini, peneliti menggunakan jenis penelitian pengembangan. Metode penelitian dan pengembangan atau yang lebih dikenal dengan sebutan Research and Development (R\&D) merupakan metode penelitian yang digunakan untuk menghasilkan produk tertentu, dan menguji keefektifan produk tersebut (Sugiono, 2014:297). Dengan demikian penelitian pengembangan merupakan salah satu bentuk penelitian yang terkait dengan peningkatan kualitas pendidikan, baik dari segi proses maupun hasil pendidikan dengan melakukan pengujian dan mengembangkan sebuah produk tentang buku ajar yang dikhususkan untuk pembelajaran tematik subtema pemanfaatan energi pada siswa kelas IV Sekolah Dasar.

Model penelitian pengembangan yang dipakai dalam penelitian ini mengadaptasi dari 
teori Borg and Gall sebagai berikut: (1) tahap pra-pengembangan, (2) tahap pengembangan produk, (3) tahap uji coba produk, (4) tahap revisi.

a. Tahap prapengembangan produk. Tujuan tahap pra pengembangan yaitu mempelajari dan mendalami karakteristik materi yang dikembangkan ke dalam bahan ajar yang direncanakan. Selain itu, untuk mengumpulkan bahan-bahan materi yang dibutuhkan untuk merancang bahan ajar. Kegiatan yang dilakukan dalam tahap ini adalah:

1) Mengkaji kurikulum. Analisis kurikulum yang dilaksanakan bertujuan untuk menentukan kompetensi dasar dan indikator. Pada tahap ini ditentukan jumlah kompetensi dasar dan indikator yang akan dikembangkan ke dalam bahan ajar. Adapun kompetensi dasar dan indikator dipilih adalah tentang pembelajaran pada subtema pemanfaatan energi di kelas IV.

2) Melakukan studi lapangan. Studi lapangan yang dilakukan bertujuan untuk mengidentifikasi perilaku dan karakteristik siswa kelas IV SD Negeri Kebonsari 1 Kota Malang, menganalisis kesulitan belajar siswa, dan menganalisis kebutuhan bahan ajar pada pembelajaran tematik subtema pemanfaatan energi siswa kelas IV SD. Kegiatan ini dilakukan dengan cara wawancara kepada guru kelas serta mengamati bahan ajar yang digunakan dalam pembelajaran tematik subtema pemanfaatan energi pada kelas IV. Hasil dari pengamatan menunjukkan bahwa bahan ajar tematik subtema pemanfaatan energi sudah mengacu pada kurikulum 2013, hanya saja kurang bervariasi sehingga terkesan menjenuhkan siswa dan bersifat monoton. Selain itu juga dikarenakan kurangnya materi yang mendukung dalam pembelajaran. Pada akhirnya hal tersebut akan membuat siswa mengalami banyak kesulitan dalam memahami materi yang disajikan, sehingga akan memengaruhi hasil belajar siswa.

3) Pengumpulan dan pemilihan bahan. Pada tahap ini, dilakukan pegumpulan dan pemilihan bahan yang digunakan dalam pengembangan bahan ajar. Bahan ajar yang dipilih disesuaikan dengan kemampuan siswa pada tingkat SD/MI kelas IV. Hasil dari proses tersebut berupa materi yang berkenaan dengan pembelajaran tematik subtema pemanfaatan energi, gambar yang akan dijadikan contoh dalam bahan ajar yang dikembangkan.

4) Menyusun kerangka bahan ajar. Penyusunan kerangka bahan ajar untuk mengelompokkan indikator, materi, evaluasi, langkah pembelajaran dari kompetensi tentang hubungan pembelajaran tematik subtema pemanfaatan energi.

b. Tahap pengembangan produk. Pada tahap ini, dilakukan pengembangan buku ajar berbasis integrasi Islam. Dalam mengembangkan materi ini, peneliti melakukan konsultasi dengan guru mata pelajaran dan beberapa pihak yang berkompeten dalam bidang pembelajaran tematik. Materi yang disajikan dalam buku ini bukanlah materi yang secara instan memperkenalkan konsep. Materi dalam pembelajaran tematik ini dilengkapi dengan percobaan-percobaan dan ada integrasi keIslaman. Adapun serangkaian proses yaitu sebagai berikut: (1) melakukan penataan isi dan struktur bahan ajar, (2) enyusunan kegiatan pembelajaran, (3) penyusunan bahan ajar dengan penambahan materi yang lebih luas, percobaan-percobaan dan integrasi Islam dalam buku ajar, (4) penyusunan perangkat evaluasi.

c. Tahap uji coba produk. Kegiatan pada tahap ini untuk mengetahui tingkat kelayakan draf awal yang dihasilkan dari tahap pengembangan sehingga bisa dilakukan perbaikan 
untuk penyempurnaa produk yang berupa bahan ajar. Pada tahap uji coba produk terdapat dua langkah yaitu tahap validasi dan tahap uji coba lapangan. Validasi produk dilakukan dengan konsultasi kelompok ahli, yakni ahli materi, ahli desain dan ahli pembelajaran. Hasil penilain dari validasi ahli dan praktisi digunakan untuk penyempurnaan produk. Setelah itu, dilakukan uji coba lapangan untuk mengetahui kelayakan bahan ajar yang telah dikembangkan.

d. Tahap Revisi Produk. Kegiatan ini dilakukan untuk perbaikan atau penyempurnaan terhadap draf awal berdasarkan analisis data atau informasi yang diperoleh dari ahli dan siswa. Apabila bahan ajar sudah dikatakan valid maka peneliti tidak perlu melakukan revisi dan produk siap untuk diimplementasikan, namun apabila bahan ajar belum dikatakan valid maka harus direvisi terlebih dahulu sebelum menjadi produk akhir pengembangan.

\section{Validasi Produk}

a. Desain Validasi. Desain validasi yang digunakan pada penelitian pengembangan ini adalah validasi ahli isi mata pelajaran, ahli desain media pembelajaran, guru sebagai ahli pembelajaran dan siswa sebagai pengguna produk. Validasi ini meliputi validasi isi dan desain produk yang digunakan. Validasi ini bertujuan untuk memperoleh data berupa penilaian dan saran-saran validator, sehingga diketahui valid tidaknya produk yang dikembangkan dan selanjutnya digunakan sebagai dasar untuk melakukan revisi.

b. Subjek Validasi. Subjek validasi dalam suatu penelitian pengembangan merupakan validator dari terdiri dari masing-masing ahli. Validasi yang dilakukan dalam penelitian ini meliputi isi materi buku ajar, desain buku ajar dan ahli pembelajaran kelas IV pada tema 2 subtema 2 adalah sebagai berikut:

1) Dosen validasi isi buku tematik subtema pemanfaatan energi:

a) Dosen PGMI yang berkompeten dalam bidang pendidikan dasar dan mamahami tentang pembelajaran tematik.

b) Memiliki latar belakang pendidikan minimal S2.

c) Mengetahui kurikulum $2013 \mathrm{SD} / \mathrm{MI}$.

2) Dosen validasi desain media:

a) Memiliki latar belakang pendidikan minimal S2.

b) Sebagai penulis buku, makalah, dan lain sebagainya sekaligus sebagai

c) pemerhati pendidikan.

d) Telah berpengalaman dalam mendesain dan merancang buku.

3) Guru

a) Sebagai guru yang telah berpengalaman mengajar sains selama 5 tahun.

b) Memahami kurikulum 2013 SD/MI.

\section{Jenis Data}

Jenis data yang diperoleh dari hasil validasi terhadap buku ajar yang telah dikembangkan ada dua acam. Data pertama berupa data kuantitatif yang diperoleh dari hasil penskoran berupa persentase untuk mengetahui kelayakan atau kevalidan buku ajar tersebut. Disamping itu, data kuantitatif juga dihimpun dengan menggunakan tes prestasi 
belajar pada pembelajaran tematik subtema pemanfaatan energi, yang meliputi pre test dan post test untuk mengukur keefektifan bahan ajar terhadap hasil belajar. Data kedua merupakan data kualitatif yang berupa tanggapan-tanggapan atau saran dari validator.

\section{Instrumen Pengumpulan Data}

Instrumen yang digunakan untuk mengumpulkan data penelitian ini adalah adalah berupa angket yang terdiri dari dua bagian. Bagian pertama merupakan instrumen pengumpulan data kuantitatif yaitu berupa angket skala Likert dengan 5 alternatif jawaban, sebagai berikut:

a. Skor 1, jika tidak jelas, tidak sesuai, tidak relevan, tidak sistematis, tidak memotivasi, tidak dapat mengukur kemampuan.

b. Skor 2, kurang jelas, kurang sesuai, kurang relevan, kurang sistematis, kurang memotivasi, kurang dapat mengukur kemampuan.

c. Skor 3, cukup jelas, cukup sesuai, cukup relevan, cukup sistematis, cukup memotivasi, cukup dapat mengukur kemampuan.

d. Skor 4, jika jelas, sesuai, relevan, sistematis, memotivasi, dapat menguku kemampuan.

e. Skor 5, jika sangat jelas, sangat sesuai, sangat relevan, sangat sistematis, sangat memotivasi, sangat dapat mengukur kemampuan.

Data keefektifan melalui tes prestasi belajar pada pembelajaran tematik subtema pemanfaatan energi menggunakan instrumen berupa tes yaitu pre-test dan post-test. Tes digunakan untuk mengumpulkan data tentang hasil yang menunjukkan perubahan pemahaman sebelum dan sesudah proses pembelajaran dengan menggunakan buku ajar tematik berbasis integrasi Islam subtema pemanfaatan energi. Sedangkan bagian kedua merupakan instrumen pengumpulan data kualitatif berupa lembar pengisian saran dan komentar dari validator.

\section{Teknik Analisa Data}

Teknik analisa data yang digunakan untuk menganalisis data kuantitatif hasil validasi dengan teknik perhitungan nilai rata-rata. Fungsi perhitungan untuk mengetahui peringkat nilai akhir untuk butir yang bersangkutan. Rumus perhitungan nilai rata-rata sebagai berikut:

$$
\mathrm{P}=\sum_{\sum \mathrm{x} 1}^{\sum \mathrm{x}} \mathrm{X} 100 \%
$$

Keterangan :

$\mathrm{P}=$ Kelayakan

$\sum_{\mathrm{x}}=$ Jumlah jawaban penilaian

$\sum_{\mathrm{x} 1}=$ Jumlah jawaban tertinggi 
Tabel 3.1 Kualifikasi Tingkatan Kelayakan Berdasarkan Persentase:

\begin{tabular}{ccc}
\hline Presentase (\%) & Kriteria kelayakan & Keterangan \\
\hline $84-100$ & Sangat Valid & Tidak Revisi \\
$68-84$ & Valid & Tidak Revisi \\
$52-74$ & Cukup Valid & Sebagian Revisi \\
$36-52$ & Kurang Valid & Revisi \\
$20-36$ & Sangat Kurang Valid & Revisi \\
\hline
\end{tabular}

Apabila skor validasi yang diperoleh minimal 68, maka buku ajar yang dikembangkan tersebut sudah dapat dimanfaatkan sebagai buku ajar dalam kegiatan belajar di sekolah.

Sedangkan analisis data pada uji coba lapangan, data dihimpun menggunakan angket dan tes prestasi atau achievement test (tes pencapaian hasil belajar). Data uji coba lapangan dikumpulkan dengan menggunakan tes awal dan tes akhir dalam rangka untuk mengetahui hasil belajar kelompok uji coba sasaran yakni kelas IV sebelum dan sesudah menggunakan produk pengembangan buku ajar. Teknik analisis data menggunakan eksperimen one group pretest posttest design yaitu sampel diberi tes awal dan tes akhir disamping perlakuan. Kriteria ujinya adalah uji t untuk amatan ulang, Uji t digunakan untuk mengetahui ada tidaknya pengaruh suatu perlakuan yang dikenakan pada sekelompok objek penelitian. Adapun rumus yang digunakan dengan tingkat kemaknaan 0,05 adalah:

$$
t=\frac{\bar{D}}{\frac{d 2}{\sqrt{N(n-1)}}}
$$

Keterangan:

$\mathrm{t}=$ uji $\mathrm{t}$

$\mathrm{D}=\operatorname{Different}(\mathrm{X} 2-\mathrm{X} 1)$

$\mathrm{d} 2=$ Variansi

$\mathrm{N}=$ Jumlah Sampel (Turmudi, 2008:214).

\section{Uji Coba Produk}

a) Desain Uji Coba; Dalam bidang pendidikan, desain produk seperti buku ajar dapat langsung diuji coba, setelah divalidasi dan revisi. Uji coba tahap awal dilakukan dengan simulasi penggunaan buku ajar tersebut. Setelah disimulasikan, maka dapat diujicobakan pada kelompok yang terbatas. Pengujian dilakukan dengan tujuan untuk mendapatkan informasi apakah buku ajar baru tersebut lebih efektif dan efisien dibandingkan buku ajar yang lama atau yang lain. Untuk pengujian buku ajar ini dilakukan dengan cara membandingkan dengan keadaan sebelum dan sesudah memakai sistem baru (before-after). 

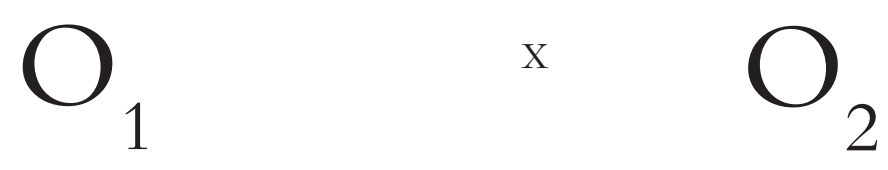

\section{Gambar 1. Desain Eksperimen (Before-After). O1 Nilai Sebelum \\ Treatment dan O2 Nilai Sesudah Treatment}

Keterangan:

$\mathrm{X}=$ pembelajaran menggunakan buku ajar dan media pembelajaran

O1 $=$ tes awal $/$ pretest

O2 = tes akhir/ post test

b) Subjek Uji Coba

Subjek uji coba dalam penelitian pengembangan ini dilakukan pada siswa siswi kelas IV SD Negeri Kebonsari 1 Kota Malang yang berjumlah 28 siswa siswi. Hal yang diteliti yaitu membandingkan hasil belajar siswa sebelum dan sesudah menggunakan buku ajar dan media pembelajaran.

\section{HASIL PENELITIAN}

\section{Pengembangan Buku Ajar}

Pengembangan buku ajar berbasis integrasi Islam subtema pemanfaatan energi ini didasarkan pada kenyataan bahwa belum tersedianya buku ajar yang didukung integrasi keIslaman, terutama yang memiliki spesifikasi pembelajaran dengan tambah luasnya materi pembelajaran di dalamnya dan dalam pembuatannya menggunakan desain majalah yang lebih menarik bagi anak.

Dengan demikian hasil ini dimaksudkan untuk dapat memenuhi tersedianya buku ajar berbasis integrasi Islam subtema pemanfaatan energi yang dapat meningkatkan kemenarikan dan hasil belajar siswa pada subtema pemanfaatan energi di SD/MI dalam mencapai hasil pendidikan yang telah ditetapkan di dalam kurikulum.

Hasil pengembangan buku ajar ini berupa buku ajar sebagai panduan siswa. Buku ajar ini telah direvisi berdasarkan hasil uji ahli isi, ahli desain pembelajaran, uji guru pembelajaran dan uji kelompok besar. Masing- masing hasil uji pengembangan buku ajar berupa buku panduan siswa ini dijelaskan pada bab IV.

Berdasarkan pengembangan buku ajar tematik berbasis integrasi Islam kelas 4 sebagai pegangan siswa dapat dilihat ciri khas buku ajar terdapat pada keluasan materi dalam buku ajar dan terdapatnya Ayat Al-Qur'an disetiap akhir pembelajaran untuk tujuan anak lebih menguasai pembelajaran tematik karena luasnya materi yang terdapat dalam buku ajar dan menambah kecintaan terhadap Al-Qur'an setiap harinya.

Sebagai aktifitas fisik, terkait dengan pelayanan belajar yang harus diberikan guru secara teknis, yakni merencanakan keterlibatan siswa agar lebih aktif belajar di rumah dan di kelas, misalnya dari menyiapkan segala kebutuhan belajar, melatih diri untuk melakukan 
kegiatan praktikum sendiri atau bersama teman, maka buku ajar ini dilengkapi dengan percobaan-percobaan yang dapat menguatkan pendalaman materi siswa. Sedangkan aktifitas mental dapat dilihat dari semangat siswa dalam belajar. Buku ajar tematik berbasis integrasi Islam ini dapat meningkatkan motivasi belajar siswa karena dilengkapi dengan gambar dan desain yang menarik yang sesuai dengan usia anak kelas IV yaitu usia $9-10$ tahun. Motivasi adalah penggerak tingkah laku kearah suatu tujuan dengan didasari suatu kebutuhan.

Hal ini penting, karena tanpa adanya perencanaan terhadap apa yang perlu dipikirkan oleh siswa selama belajar maka hasilnya akan sia-sia. Oleh karena itu siswa tidak harus berfikir dengan yang hanya menggutamakan kemampuan otak tetapi di dasari dengan keinginan hati. Sehingga keterlibatannya secara emosional benar-benar memberi manfaat terhadap diri dan lingkungan belajarnya.

Guna untuk mengarahkan siswa agar memiliki ketrampilan secara praktis dan terlatih mentalnya, dalam pengembangan ini dilakukan inovasi secara realistik (Tabrani Rusyan, 1994:99). Inovasi secara realistik ini sesuai dengan kurikulum 2013 yang melibatkan siswa secara langsung mengaitkan dengan kehidupan sehari-hari.

Pembelajaran tematik dimaknai sebagai pembelajaran yang dirancang berdasarkan tema-tema tertentu. Pengembangan buku ajar ini lengkap dengan kegiatan yang menunjang siswa secara aktif yang mengikuti prinsip $5 \mathrm{M}$ yaitu mengamati, mencoba, menalar, menanya dan mengkomunikasikan. Selama di sekolah/madrasah, siswa mulai terbiasa berpikir reproduktif, yaitu menggali ingatan pemahaman yang diperoleh selama menggunakan bahan ajar. Hal ini dikarenakan karena di dalam buku ajar itu memuat aktivitas yang mengajak siswa berpikir terarah guna menyelesaikan bermacam- macam masalah dalam materi pembelajaran terkait subtema pemanfaatan energi.

Hal ini dikarenakan buku ajar dilengkapi praktikum percobaan dan materi yang lebih luas untuk membantu, melayani, memotivasi dalam menyediakan informasi sesuai perkembangan siswa. Sebagai upaya melayani belajar, siswa diposisikan sebagai subjek bukan objek. Siswa benar-benar dilatih, dibina, diarahkan dari berbagai problem kehidupan yang sifatnya sederhana sampai yang kompleks terutama yang berhubungan dengan subtema pemanfaatan energi. Adapun langkah srategis yang dilakukan guru adalah membiasakan anak menggali informasi sesuai materi belajarnya yang sudah dirancang dengan menggunakan pengembangan buku ajar tematik berbasis integrasi Islam subtema pemanfaatan energi (Trianto, 2011:147).

Cara ini menunjukkan proses pembelajaran di kelas 4 SD Negeri Kebonsari 1 Kota Malang kurang berjalan dengan baik karena buku tematik dari pemerintah materinya kurang lengkap dan hanya menunjuk pada inti pembelajaran, yang membuat siswa kurang mengerti terhadap materi yang berkaitan dengan materi subtema pemanfaatan energi.

Selama pengembangan buku ajar di SD Negeri Kebonsari 1 Kota Malang berlangsung, pada dasarnya diawali dengan menetapkan masalah yang dijaring melalui angket dan wawancara, ada tiga hal yang mendasari, yaitu pertama siswa kurang aktif dalam membaca dan belajar. Kedua, guru tergantung pada buku-buku dari pemerintah saja, tanpa ada inisiatif untuk mengembangkan buku ajar sesuai kebutuhan siswa. Ketiga, terkait dengan model pembelajaran guru tematik kelas 4 .

Berdasarkan hasil informasi, maka dipilihnya langkah-langkah pengembangan bahan 
ajar, yakni model pengembangan Borg and Gall yang di dalamnya terdapat 10 tahapan desain pembelajaran. Langkah-langkah pendekatan sistem desai pembelajaran Borg and Gall di atas dapat dipaparkan sebagai berikut:

a. Analisis kebutuhan dengan menentukan tujuan program atau produk yang akan dikembangkan.

b. Analisis pembelajaran dengan mengidenifikasikan keterampilan-keterampilan yang harus dipelajari siswa untuk mencapai tujuan pembelajaran.

c. Analisis pembelajar dan konteks dengan mengidentifikasi psikologi perkembangan anak pada kelas IV yaitu usia 9 - 10 tahun.

d. Tujuan pembelajaran khusus dengan merumuskan kemampuan atau perilaku yang diharapkan dapat dimiliki oleh siswa sesudah menggunakan produk pengembangan.

e. Mengembangkan instrumen yang didasarkan pada tujuan khusus dengan memberikan soal pre tes dan post-tes terdiri dari sepuluh soal pilihan ganda dan enam essay.

f. Mengembangkan strategi pembelajaran dengan upaya memilih, menata, dan mengembangkan komponen-komponen umum pembelajaran dan prosedurprosedur yang akan digunakan untuk membelajarkan peserta didik sehingga peserta didik dapat belajar dengan mudah sesuai karakteristiknya dalam mencapai tujuan pembelajaran yang telah ditetapkan.

g. Mengembangkan dan memilih bahan pembelajaran dengan hasil produk pengembangan berupa printed material yang berupa buku ajar pembelajaran tematik berbasis integrasi Islam kelas IV SD/MI subtema pemanfaatan energi.

h. Merancang dan melakukan evaluasi formatif pada 2 kelompok, yaitu evaluasi oleh para ahli dan evaluasi penggunaan buku ajar bagi peserta didik. Evaluasi para ahli meliputi uji ahli isi bidang studi untuk melihat kebenaran isi yang tersaji, ahli desain untuk memperoleh kesesuaian desain yang dikembangkan, dan ahli pembelajaran untuk memperoleh kesesuaian tingkat kesulitan materi dengan peserta didik.

Sedangkan dalam evaluasi bagi peserta didik ditunjukkan pada uji coba lapangan (filed evaluation).

1) Melakukan revisi dengan mengkaji data dari hasil evaluasi formatif.

2) Evaluasi sumatif dengan memproduksi buku ajar dan media pembelajaran yang telah direvisi dalam pembelajaran untuk diterapkan dan melihat apakah produk tersebut mampu membuat nilai siswa lebih baik dari yang sebelumnya. Tujuan pembelajaran ini difokuskan pada peningkatan hasil belajar siswa.

Upaya peningkatan hasil belajar siswa melalui pembelajaran dengan buku ajar tematik berbasis integrasi Islam subtema pemanfaatan energi. Adapun sajian materi yang tertulis dalam buku ajar ini yaitu lebih memperhatikan unsur konsep yang sesuai dengan realita dan dengan gambar-gambar sebagai contoh dalam materi. Untuk keperluan ini, peneliti mengumpulkan dan menyeleksi bahan kepustakaan yang relevan serta informasi-informasi aktual di buku-buku SD/MI, internet dan sumber-sumber lain. materi disusun dengan banyak memberikan peluang berpikir dan menggunakan bahasa yang mudah dipahami siswa. 


\section{Hasil Validasi Ahli}

Analisi hasil validasi ahli isi pembelajaran tematik terhadap Buku Ajar'Tematik Berbasis Integrasi Islam Subtema Pemanfaatan Energi untuk Kelas IV SD/MI menunjukkan 1) Tingkat relevansi buku ajar dengan kurikulum yang berlaku sangat relevan, 2) rumusan topik pada pengembangan buku ajar sesuai, 3) Kemudahan bahasa untuk dipahami dalam buku ajar sangat mudah, 4) Penambahan integrasi keIslaman pada buku ajar tepat, 5) Ruang lingkup materi yang disajikan pada buku ajar sangat sesuai, 6) Komponen isi buku sudah sangat memadai sebagai buku ajar, 7) Keluasan dan kedalaman isi buku ajar sangat luas, 8) Keruntutan penyajian materi sagat runtut, 9) Melalui buku ajar meningkatkan semangat siswa sangat memotivasi, 10) Keterencanaan uraian materi sesuai .

Dari angket tanggapan yang diisi oleh Agus Mukti Wibowo, M.Pd sebagai ahli isi, dapat dihitung persentase tingkat kevalidan buku ajar sebesar 94\%. Sesuai dengan tabel konversi skala, persentase tingkat pencapaian 94\% berada pada kualifikasi sangat valid sehingga buku ajar tidak perlu dilakukan revisi.

Sedangkan data hasil validasi ahli desain media terhadap Buku Ajar Tematik Berbasis Integrasi Islam Subtema Pemanfaatan Energi untuk Kelas IV SD/MI menunjukkan 1) Kemenarikan pengemasan desain cover buku ajar menarik, 2) Kesesuaian gambar pada cover pada buku ajar sangat sesuai, 3) Kesesuaian judul pada setiap pembelajaran dan pemilihan gambar pada buku ajar sangat sesuai, 4) Kesesuaian pemakaian jenis huruf yang digunakan cover pada buku ajar sesuai, 5) Ketepatan layout pengetikan buku ajar sangat tepat, 6) Konsistensi penggunaan spasi dan pengetikan materi sangat konsisten, 7) Ketepatan penempatan gambar pada setiap pembelajaran dalam buku ajar tepat, 8) Kesesuaian penggunaan variasi jenis, ukuran dan bentuk huruf untuk judul setiap pembelajaran sesuai, 9) Kesesuaian penggunaan variasi jenis, ukuran dan bentuk huruf untuk judul setiap percobaan sesuai, 10) Ketertarikan kombinasi warna yang digunakan dalam mendesain buku ajar sangat menarik.

Dari angket tanggapan yang diisi oleh Ahmad Abtokhi, M.Pd sebagai ahli desain media, dapat dihitung persentase tingkat kevalidan buku ajar dan media pembelajaran sebesar 90\%. Sesuai dengan tabel konversi skala, persentase tingkat pencapaian 90\% berada pada kualifikasi valid sehingga buku ajar tidak perlu dilakukan revisi.

Adapun hasil validasi ahli pembelajaran tematik kelas IV terhadap Buku Ajar Tematik Berbasis Integrasi Islam Subtema pemanfaatan Energi Kelas IV SD/MI berdasarkan pada tabel 4.5 menunjukkan 1) Rumusan topik pada pengembangan buku ajar tematik subtema pemanfaatan energi sangat jelas, 2) Kesesuaian materi yang disajikan pada pengembangan buku ajar tematik subtema pemanfaatan energi sesuai, 3) Relevansi kompetensi dasar dengan indikator pada pengembanganbuku ajar tematik subtema pemanfaatan energi sangat relevan, 4) Isi pembelajaran dalam buku ajar sesuai dengan kurikulum 2013 sesuai, 5) Sistematik uraian isi pembelajaran dalam buku ajar tematik subtema pemanfaatan energi sangat sistematik, 6) Ruang lingkup materi yang disajikan dalam buku ajar tematik subtema pemanfaatan energi sangat sesuai dengan tema, 7) Materi yang disajikan melalui buku ajar tematik subtema pemanfaatan energy sangat memberikan motivasi kepada siswa agar lebih giat belajar, 8) Tingkat kesukaran bahasa yang digunakan dalam buku ajar sangat sesuai dengan tingkat pemahaman siswa, 9) Keluasan dan kedalaman isi buku ajar tematik subtema pemanfaatan energy sangat luas, 10) Instrumen evaluasi yang di ukur sangat dapat mengukur kemampuan siswa. 
Dari angket tanggapan yang diisi oleh guru mata pelajaran kelas IV SDN Kebonsari 1 Kota Malang sebagai ahli pembelajaran tematik, dapat dihitung persentase tingkat kevalidan buku ajar sebesar 94\%. Sesuai dengan tabel konversi skala, persentase tingkat pencapaian 94\% berada pada kualifikasi sangat valid sehingga buku ajar tidak perlu dilakukan revisi.

\section{Kemenarikan Buku Ajar Tematik Berbasis Integrasi Islam Subtema Pemanfaatan Energi untuk Kelas IV}

Hasil validasi buku ajar pada uji coba kelompok terhadap pengembangan Buku ajar Sains Berbasis Integrasi Islam Subtema Pemanfaatan Energi Subtema Pemanfaatan Energi untuk kelas IV di SD Negeri Kebonsari 1 Kota Malang dinilai baik dengan prosentase 92\% dari kriteria yang ditetapkan. Hasil penilaian uji coba lapangan pada setiap komponen sebagaimana dianalisis secara kuantitatif dapat diinterpretasikan sebagaimana berikut:

a. Kemudahan dalam belajar dengan menggunakan buku ajar tematik berbasis integrasi Islam subtema pemanfaatan energi diperoleh penilaian dengan persentase sebesar 88\%. Hal ini menunjukkan bahwa buku ajar dapat memudahkan siswa dalam belajar.

b. Penggunaan buku ajar tematik berbasis integrasi Islam subtema pemanfaatan energi ini dapat memberi semangat dan menimbulkan rasa keingintahuan dalam belajar mendapatkan penilaian dengan persentase sebesar 97\%. Hal ini menunjukkan bahwa dengan menggunakan buku ajar tematik subtema pemanfaatan energi ini, dapat memberi semangat dalam belajar siswa.

c. Buku ajar tematik berbasis integrasi Islam subtema pemanfaatan energy memudahkan siswa memahami bahan pelajaran mendapatkan penilaian dengan persentase sebesar 90\%. Hal ini menunjukkan bahwa buku ajar tematik subtema pemanfaatan energi ini dapa memudahkan siswa dalam memahami bahan pelajaran.

d. Soal-soal pada buku ajar tematik berbasis integrasi Islam subtema pemanfaatan energi mudah, mendapatkan penilaian dengan persentase sebesar 84\%. Hal ini menunjukkan bahwa soal-soal pada buku ajar tematik subtema pemanfaatan energi sudah sesuai dengan materi dan dapat dipergunakan karena memiliki tingkat keefektifan dan kemenarikan yang tinggi dalam belajar.

e. Jenis huruf dan ukuran huruf yang terdapat dalam buku ajar tematik berbasis integrasi Islam subtema pemanfaatan energi ini mudah dibaca mendapatkan penilaian dengan persentase sebesar 93\%. Hal ini menunjukkan bahwa Jenis huruf dan ukuran huruf yang terdapat dalam buku ajar tematik subtema pemanfaatan energi mempermudah siswa dalam membaca.

f. Kata-kata yang digunakan dalam buku ajar tematik berbasis integrasi Islam subtema pemanfaatan energi mendapatkan penilaian dengan persentase sebesar $90 \%$. Hal ini menunjukkan bahwa kata-kata yang digunakan sesuai dengan karakter siswa.

g. Petunjuk yang terdapat dalam buku ajar tematik berbasis integrasi Islam subtema pemanfaatan energi mendapatkan penilaian dengan persentase sebesar 92\% menyatakan sangat mudah dalam memahami petunjuk penggunaan. Hal ini menunjukkan bahwa siswa mudah dalam menggunakan buku ajar.

h. Bahasa yang digunakan dalam buku ajar dan media pembelajaran tematik berba- 
sis integrasi Islam subtema pemanfaatan energi mendapatkan penilaian dengan persentase sebesar 94\%. Hal ini menunjukkan bahwa bahasa yang digunakan sudah sesuai dengan karakteristik siswa.

i. Soal-soal latihan dalam buku ajar tematik berbasis integrasi Islam subtema pemanfaatan energi mendapatkan penilaian dengan persentase sebesar 93\%. Hal ini menunjukkan bahwa soal-soal latihan mudah dipahami siswa.

j. Buku ajar tematik berbasis integrasi Islam subtema pemanfaatan energi ini membantu siswa untuk bekerjasama dengan teman dan lingkungan mendapatkan penilaian dengan persentase sebesar $92 \%$. Hal ini menunjukkan bahwa buku ajar ini sangat membantu siswa untuk bekerjasama dengan teman dan lingkungan.

Angket tanggapan yang diisi oleh 28 subyek uji coba yaitu siswa kelas IV SD Negeri Kebonsari 1 Kota Malang, dapat dihitung secara keseluruhan persentase tingkat kevalidan buku ajar sebesar 92\%. Sesuai dengan tabel konversi skala, persentase tingkat pencapaian $92 \%$ berada pada kualifikasi sangat valid sehingga buku ajar tidak perlu dilakukan revisi.

\section{Pengaruh Buku Ajar Tematik Berbasis Integrasi Islam Subtema pemanfaatan Energi untuk Kelas IV}

Buku ajar yang dikembangan merupakan upaya untuk memperbaiki hasil belajar siswa di kelas 4 SD Negeri Kebonsari 1 Kota Malang. Menurut Suharta buku ajar adalah buku yang digunakan baik oleh siswa maupun guru dalam kegiatan belajar mengajar. Materi dalam buku ajar merupakan realisasi dari materi yang tercantum dalam kurikulum.

Banyak sekali faktor yang mempengaruhinya, baik dari dalam atau luar individu. Tugas dari guru adalah mengkondisikan lingkungan itu. Agar menunjang terjadinya perubahan tingkah laku siswa. Oleh karena itu yang ditempuh oleh guru tematik adalah pretest, proses, dan postest.

Produk pengembangan yang diserahkan untuk uji coba lapangan pembelajaran tematik subtema pemanfaatan energi adalah berupa buku ajar. Produk pengembangan diserahkan kepada kelas uji coba lapangan dengan jumlah koresponden sebanyak 28 koresponden. Pretest merupakan tahap awal yang dilakukan peneliti, hal ini dilakukan untuk menjajahi proses pembelajaran tematik subtema pemanfaatan energi melalui pengembangan buku ajar tematik berbasis integrasi Islam subtema pemanfaatan energi. Adapun hasil pretest ini kurang memuaskan, nampak siswa masih kesulitan dalam menjawab soal-soal yang sederhana dengan nilai rata-rata dari 28 siswa masih mencapai 71, belum mencapai ketuntasan. Selanjutnya dilakukan proses pembelajaran tematik subtema pemanfaatan energi dengan menggunakan buku ajar yang sudah dikembangkan yaitu buku ajar tematik berbasis integrasi Islam subtema pemanfaatan energi.

Pengembangan buku ajar ini dalam proses pembelajarannya terdapat materi yang luas dan dilengkapi dengan percobaan-percobaan yang membuat siswa lebih memahami materi subtema pemanfaatan energi. Buku ajar ini dilengkapi Ayat Al- Qur'an yang berkaitan dengan materi pembelajaran sehingga setiap harinya siswa akan membaca Ayat Al- Qur'an dan membuat siswa lebih mencintaiAl-Qur'an setiap harinya.

Kegiatan selanjutnya untuk mengetahui pengaruh buku ajar terhadap hasil belajar siswa dengan menggunakn postest. Nilai dalam postest ini sangat memuaskan karena dibuktikan dengan nilai rata-rata 28 siswa yaitu 91 dan semuanya mencapai kriteria 
ketuntasan dalam KKM. Hasil perhitungan menunjukkan bahwa thitung lebih besar ttabel maka Ho ditolak dan Ha diterima, sehingga terdapat perbedaan yang signifikan antara nilai siswa sebelum dan sesudah menggunakan buku ajar temmatik berbasis integrasi Islam subtema pemanfaatan energi. Selanjutnya dari rata-rata diketahui X2 lebih dari X1 (90,57 $>71,14$ ) juga menunjukkan bahwa post tes lebih bagus dari pada pre test. Hal tersebut menunjukkan bahwa buku ajar temmatik berbasis integrasi Islam subtema pemanfaatan energi mampu meningkatkan prestasi belajar siswa.

\section{KESIMPULAN}

Berdasarkan proses pengembangan dan hasil penilaian terhadap Buku Ajar Tematik Berbasis Integrasi Islam Subtema Pemanfaatan energi Untuk Kelas IV ini dapat dipaparkan beberapa hal sebagai berikut:

1. Buku ajar sains berbasis Integrasi Islam subema pemanfaatan energi untuk kelas IV terdiri dari bagian. a) Pra-pendahuluan terdiri dari sampul depan, sampul belakang, kata pengantar, dan daftar isi; b) Isi terdiri dari 6 pembelajaran tentang subtema pemanfaatan energi dan 8 permainan percobaan, diantaranya adalah 5 percobaan mengenai perpindahan panas yaitu tentang konduksi, konveksi dan radiasi, 3 permainan mengenai membuat kreasi-kreasi yang dapat mengembangkan daya kreatif siswa; dan c) bagian pendukung mari belajar, mari mencoba, mari renungkan, mari bekerja sama, mari berkreasi, mari kerjakan, bekerjasama dengan orag tua, ayat AlQur'an disetiap akhir pembelajaran dan daftar pustaka.

2. Buku ajar tematik berbasis integrasi Islam subtema pemanfaatan energi yang telah dikembangkan mendapat penilaian kualifikasi yang baik, karena berdasarkan hasil validasi diperoleh nilai dari guru mata pelajaran sebesar $94 \%$ yang berarti buku ajar tematik subtema pemanfaatan energi sangat valid dan tidak perlu revisi, dari uji coba lapangan buku ajar tematik subtema pemanfaatan energi diperoleh nilai $92 \%$ yang berarti mendapat kualifikasi sangat valid dari semua subyek validasi uji coba lapangan. Dari ahli isi mendapat nilai 94\% dan berada pada kualifikasi sangat valid sehingga tidak perlu revisi, dari ahli desain media mendapat nilai $90 \%$ dan berada pada kualifikasi valid, sehingga buku tidak perlu revisi. Tetapi, buku akan tetap diperbaiki berdasarkan saran dan komentar dari masing-masing subyek validasi.

3. Buku ajar tematik berbasis integrasi Islam subtema pemanfaatan energi terbukti secara signifikan efektif untuk meningkatkan prestasi pada pembelajaran tematik subtema pemanfaatan energi pada siswa kelas IV di SD Negeri Kebonsari 1 Kota Malang. Hal ini dibuktikan dengan perhitungan menggunakan uji t dengan tingkat kemaknaan 0,05 diperoleh hasil thitung2 $\geq$ t2 tabel yaitu 3,891015 $\geq 1,701$ artinya Ho ditolak dan Ha diterima. Selanjutnya dari rata-rata diketahui X2 lebih dari X1 $(90,57>71,14)$ juga menunjukkan bahwa post tes lebih bagus dari pada pre test. Kesimpulannya terdapat perbedaan yang signifikan pada prestasi belajar siswa kelas IV sesudah menggunakan buku ajar tematik berbasis integrasi Islam subtema pemanfaatan energi dengan prestasi belajar sebelum menggunakan buku ajar tematik berbasis integrasi Islam subtema pemanfaatan energi di SD Negeri Kebonsari 1 Kota Malang. 


\section{DAFTAR PUSTAKA}

Al-Munawar, Said Agil Husin. 2003. Aktualisasi Nilai-nilai Qur'ani: dalam Sistem Pendidikan Islam. Jakarta: Ciputat Press

Amri, Sofan,dkk. 2011. Konstruksi Pembelajaran Pengaruhnya Terhadap Mekanisme dan Praktek Kurikulum. Jakarta: PT. Preatasi Pustakarya

Arsyad, Azhar. 1997. Media Pengajaran. Jakarta: PT RajaGrafindoPersada 1997

Asnawir dan Usman, Basyiruddin. 2002. Media Pembelajran. Jakarta: PT Intermasa

Bahan Ajar, Buku Ajar, Buku Teks, Buku Penunjang, Media dan Buku Referensi. http:/ / scribd.com/doc/37662544/BAHAN-AJAR-makalah-1.html. Diakses 20 April 2015 jam 14.47 WIB.

Belawati, Tia. 2003. Materi Pokok Pengembangan Bahan Ajar Edisi ke Satu. Jakarta: Universitas Terbuka.

Dahar, Ratna Wilis. 1989. Teori- Teori Belajar. Bandung. Erlangga

Degeng, I Nyoman Sudan. 1989. Ilmu Pengajaran Taksonomi Variabel. Jakarta: Depdikbud Dirjen Perguruan Tinggi Proyek Lembaga Pengembangan Lembaga Pendidikan dan Kependidikan

Hartono. 2012. Pengembangan Bahan Ajar Pendidikan Agama Islam Berbasis Pembelajaran Tematik pada Siswa kelas III MI. Jakarta: Kemenag RI

http:/ / rahdinalspaceart.blogspot.com/2011/11/definisi-majalah-majalahadalah-sebuah. html (online) 12 April 2014

Ibrahim, Muhammad Ismail. 1986. Sisi Mulia Al-Qur'an. Jakarta : CV.Rajawali

Jamaluddin, Muhammad. 2004. Al- Qur'an Tentang Alam Semesta. Jakarta: Amzah

Muharam, Aris. 2008. Senang Belajar Ilmu Pengetahuan Alam untuk Kelas IV. Jakarta: Pusat Perbukuan, Departemen Pendidikan

Mulyana. 2004. Mengartikulasikan Pendidikan Nilai. Bandung: Alfabeta

Mustamir. 2007. Sembuh dan Sehat dengan Mukjizat Al-Qur'an. Yogyakarta: Penerbit Lingkaran

Nurachmadani, Setya. 2008. Ilmu Pengetahuan Alam Bse Kelas 4. Jakarta: Pusat Perbukuan, Departemen Pendidikan

Prastowo, Andi. 2011. Panduan Kreatif Membuat Bahan Ajar Inovatif. Jogjakarta: Diva Press

Pribadi, Benny A. 2010. Model Desain System Pembelajaran. Jakarta: Dian Rakyat

Rahman, Chaerul. Pengertian Integrasi Islam dalam Pembelajaran Sains di Sekolah. http:/ / chaerulgg.blogspot.com/2013/11/pengertian-integrasi-Islam.html. Diakses 29 April 2015 jam 16.02 WIB

Rosidah, Kholifatur. 2005. Pengembangan Buku Ajar Matematika Materi Pokok Peluang untuk SMP Kelas IV Mengacu Kurikulum 2004. Skripsi tidak diterbitka: Universitas Negeri Malang

Rusyan, Tabrani dkk. 1994. Pendekatan Dalam Proses Belajar Mengajar. Bandung: Remaja Rosdakarya

Selyasari, Punaji. 2010. Metode Penelitian Pendidikan dan Pengembangan. Jakarta: 